\title{
Perception Toward Quarantine for COVID-19 Among Adult Residents of Selected Towns in Southwest Ethiopia
}

This article was published in the following Dove Press journal: International Journal of General Medicine

\author{
Yitagesu Mamo' \\ Adane Asefa (D) ${ }^{2}$ \\ Qaro Qanche (iD ${ }^{2}$ \\ Tadesse Dhuguma ${ }^{3}$ \\ Asrat Wolde ${ }^{4}$ \\ Tadesse Nigussie (iD) ${ }^{2}$ \\ 'Department of Pharmacy, College of \\ Health Science, Mizan-Tepi University, \\ Mizan-Aman, Ethiopia; ${ }^{2}$ Department of \\ Public Health, College of Health Science, \\ Mizan-Tepi University, Mizan-Aman, \\ Ethiopia; ${ }^{3}$ Department of Medical \\ Laboratory Science, College of Health \\ Science, Mizan-Tepi University, Mizan-Aman, \\ Ethiopia; ${ }^{4}$ Department of Nursing, College \\ of Health Science, Mizan-Tepi University, \\ Mizan-Aman, Ethiopia
}

Background: COVID-19 is a global pandemic caused by a transmissible respiratory virus, SARS-Cov-2. Because it is a novel pathogen, limited information is available to characterize the spectrum of clinical illness, transmission efficiency, and the duration of viral shedding for patients with COVID-19. Quarantine is an important component of a multilayered strategy to prevent sustained spread of COVID-19 everywhere. The aim of this study was to assess public perceptions toward quarantine for COVID-19 and associated factors among adult residents of selected towns in Southwest Ethiopia, 2020.

Methods: The community-based cross-sectional study was conducted from 1 to 15 June 2020 among adult residents of selected towns in south west Ethiopia. Systematic random sampling was used to select 844 participants. A structured and intervieweradministered questionnaire was used to collect data. Descriptive statistics were used to describe different variables. Multiple linear regression was carried out to determine the predictors of outcome variables. In multiple linear regression, variables with $p$-value $<0.05$ were taken as statistically significant association with community perception toward quarantine.

Results: The total of 816 study participants were interviewed from which 450 (55.1\%) were male. The median age of respondents was 30 years. Four hundred and twenty-seven $(52.3 \%)$ of the respondents have a positive perception toward quarantine. Factors associated with perception toward quarantine were having training on COVID-19 $(\beta=2.76, p=0.005)$, educational status of secondary $(\beta=2.73, p=0.001)$, educational status to above secondary $(\beta=2.24$, $p=0.011$, occupational status of merchant $(\beta=1.73, p=0.020)$, and knowledge of COVID-19 $(\beta=0.23, p=0.001)$.

Conclusion: Only $52.3 \%$ of the respondents have a positive perception toward quarantine. Having training on COVID-19, educational status of secondary and above, being a merchant, knowledge of COVID-19 and knowledge of quarantine were significantly associated with a positive perception toward quarantine. Concerned bodies should work on enhancing the awareness of the community through information education and communication/behavior changing communication materials.

Keywords: community perception, quarantine, COVID-19, SARS-Cov-2, Southwest Ethiopia

\section{Background}

Department of Pharmacy, College of Health Science, Mizan-Tepi University,

Mizan-Aman, Ethiopia

Tel +251910898795

Email mamoyitagesu@gmail.com
Coronavirus disease 2019 (COVID-19) is an illness caused by a novel coronavirus called severe acute respiratory syndrome coronavirus 2 (SARS-CoV-2), which was first identified as an outbreak of respiratory illness cases in Wuhan City, Hubei 
Province, China ${ }^{1,2}$ Currently more than 16.5 million individuals were infected and more than 650,000 died from COVID-19 as of July 30, 2020. ${ }^{3}$ In Africa more than 750,000 people were infected and 12,795 died while in Ethiopia about 16,000 people were infected and 253 died of COVID-19 as of July 30, 2020. ${ }^{3}$

A broad range of public health strategy would be employed against a pandemic disease like COVID-19, from relatively innocuous techniques, such as disease surveillance and hygienic measures, to considerably more restrictive interventions, such as social distancing, travel restrictions, quarantine, and case isolation. There is hope that public health interventions will be able to slow the pandemic. By reducing the rate of spread of the disease, public health countermeasures can buy time for the development of medical countermeasures while also helping to ensure that the health-care system does not become overwhelmed by a surge of patients. Unfortunately, each type of public health intervention raises serious ethical and human rights concerns. ${ }^{4}$

Quarantine is among those public health strategies that keeps people who have been exposed to a highly contagious illness separate from people who have not been exposed. ${ }^{5,6}$ It is also a public health measure designed to reduce the potential for the spread of diseases that are considered to be of major public health concern, and for which vaccines and treatments are not readily available., ${ }^{7,8}$

Quarantine has been used for many centuries as a strategy to control epidemic diseases that threaten to spread nationally or internationally, with the first formal system being documented in Italy during the fourteenth century plague epidemic. ${ }^{9}$ Quarantine may be used under the following conditions such as if a person or a welldefined group of people have been exposed to a highly dangerous and highly contagious disease, resources are available to care for quarantined people, and resources are available to implement and maintain the quarantine and deliver essential services. ${ }^{6,9}$ Quarantine applies for people who have been exposed to a contagious disease but who may or may not become ill. ${ }^{10}$ Relative to other health policy areas, literature on quarantine tends to lack quantitative expressions of effectiveness, or agreement on how best to report differences in outcomes attributable to control measures. $^{11}$

Study revealed that interventions, such as intensive contact tracing, quarantine and isolation, can effectively reduce and control reproduction number and transmission risk of COVID-19. However, the effect of travel restriction is almost equivalent to increasing quarantine by a 100 thousand baseline value. ${ }^{12}$

Developing countries, however, face distinct pressures and constraints which make it significantly harder for them to enact effective stimulus without facing binding foreign exchange constraints. ${ }^{13}$ If it is not controlled early a devastating outcome may happen related to COVID-19. Food Aid Organization is seeking USD 110 million to maintain the provision of critical assistance where there are already high levels of need, while meeting new needs emerging from the effects of COVID-19. ${ }^{14}$

Ethiopia is a major African airline gateway. Since the COVID-19 pandemic Ethiopia started screening passengers at Bole international airport and used a laboratory in South Africa for confirmation of suspected cases. Laboratory tests for COVID-19 started on February 7, 2020 in the country. ${ }^{15}$ At the beginning the country dedicated one hospital (COVID-19), Eka Kotebe Hospital for isolation and treatment of COVID-19 cases. Now, the treatment and testing facilities are being expanded to cities outside the capital. The first COVID-19 case was identified on March 2020 in the country. Quarantining of passengers for 14 days, isolation, testing, and contact tracing was actively conducted by repurposing different hotels and universities. The government called on the residents to implement physical distancing, hand washing, and cough hygiene. $^{16}$

If appropriate preventive measures are not implemented the burden COVID-19 is more severe in developing nations because of limited resources. Quarantine and travel bans are often the first response against new infectious diseases. Despite the breadth and allure of travel bans and mandatory quarantine, an effective response to COVID-19 requires newer, more creative legal tools. With COVID-19 in our communities, the time has come to imagine and implement public health laws that emphasize support rather than restriction. ${ }^{17}$ Study also revealed that COVID-19 severity, self-efficacy, and preventive behaviors uniquely predicted mental health over and above gender, age, and chronic diseases. ${ }^{18}$ In addition to this, community risk perception correlates with adoption of preventative health behaviors. ${ }^{19}$

Different activities are being undertaken to combat COVID-19. The World Health Organization (WHO) is working closely with the International Air Transport Association (IATA) and have jointly developed a guidance document to provide advice to cabin crew and airport workers, based on country queries. ${ }^{20}$ In the 
early days of China's response to the COVID-19 outbreak, leaders recognized the behavioral health impact of the outbreak and response efforts on citizens. ${ }^{21}$

Mandatory public health measures like quarantine are essential to combat infectious diseases, especially for new emerging infectious diseases like COVID-19 where no vaccine or cure exists. Therefore, high adherence rate to this public measure has a critical role in a successful control of pandemic disease; however, some individuals are reluctant to comply with a quarantine, perhaps owing to uncertainty, scarce information, economic pressure, and a widespread perception of loss of control. ${ }^{22}$ In contrast loneliness, social boycott and pressure to quarantine are among factors mentioned as suicide causalities. ${ }^{23,24}$ During the 2003 pandemic of severe acute respiratory syndrome, the use of quarantine, border controls, contact tracing, and surveillance proved effective in containing the global threat in just over three months. ${ }^{25}$

In Ethiopia, only little is known about lay perceptions of and attitudes toward its modern-day use of quarantine. In view of the evidence of potential adverse effects on individual well-being and psychosocial health, and owing to the critical necessity of high compliance in the event of a major infectious disease outbreak, it is increasingly important to understand how quarantine is perceived by the public. Determining prevailing public attitudes toward the use of quarantine as a means of infectious disease control is a critical issue to increase its use among suspected individuals. Therefore, the aim of this study was to assess community perception toward quarantine for COVID-19 and associated factors among adult residents of selected towns in Southwest Ethiopia, 2020.

\section{Methods}

\section{Study Setting and Period}

The study was conducted in Mizan-Aman, Bonga and Tepi towns among adult residents from 1 to 15 June 2020. Mizan-Aman town is located $561 \mathrm{~km}$ southwest of Addis Ababa which is the capital city of Ethiopia. Bonga town is located to the southwest direction $460 \mathrm{~km}$ from Addis Ababa while Tepi town is located $611 \mathrm{~km}$ southwest of Addis Ababa. There is one health center and one general hospital in each town. In the three selected towns there are places prepared for public quarantine sites.

\section{Study Design and Population}

Community-based cross-sectional study triangulated with qualitative data collection was conducted. All adult population found in selected towns in Bonga, MizanAman, and Tepi towns were the source population while randomly selected adult population found in the towns were study population. Adult individuals who were residents of study area for at least six months were included while adults who were unable to hear and severely ill during the data collection time were excluded from the study.

\section{Sample Size and Sampling Technique}

Sample size for quantitative study: the sample was determined using single population proportion formula ${ }^{26}$ based on the following assumptions $\mathrm{n}=\left[\left(Z^{a / 2}\right)^{2} * p(1-p)\right] / d^{2}$ Where, $n=$ sample size, $Z \alpha / 2=$ standard score for $95 \%$ confidence level (1.96), $p=50 \%$ proportion of positive perception. $\mathrm{n}=\left[(1.96)^{2} * 0.5(1-0.5)\right] /(0.05)^{2}=385$. By adding $10 \%$ nonresponse the sample size became 422 . Using design effect of two the final sample size was 844 .

Sample size for qualitative study: in-depth interview was conducted among selected community members in selected towns. Five in-depth interviews from each town, a total of 15 in-depth interviews were conducted.

Sampling technique for quantitative study: the three towns Mizan-Aman, Bonga, and Tepi were purposely selected because of the large population size and high mobility of people across them. Systematic random sampling was used to select the study participants. Thirty percent of kebeles were selected from each town ie, two from Mizan-Aman (Kometa and Idget), one from Bonga (Kebele-02) and one from Tepi town (Andinet). Sample size was proportionally allocated from selected kebeles based on their total households. Accordingly, 206 allocated for Kometa, 217 for Ideget, 168 for Kebele 02, and 253 for Andinet. K was calculated by dividing total households in the kebele to total sample size, and it became nine. Since there is a possibility of more than one adult from each household, a lottery method was used to select one adult from those households.

Sampling technique for qualitative study: purposive/ judgmental sampling technique was employed in order to obtain individuals with detail information about perception of community toward quarantine. Elders and development army leaders were selected.

\section{Data Collection Procedures and Instruments}

The questionnaire was adapted from related literature. ${ }^{27} \mathrm{It}$ has four parts including sociodemographic, knowledge of 
COVID-19, knowledge about quarantine, and perception toward quarantine. The questionnaire was pretested on $5 \%$ of the sample size in Kite town which is $8 \mathrm{~km}$ away from Mizan-Aman town.

\section{Data Collection Process and Management}

Data were collected by trained data collectors. Diploma nurses were recruited for data collection. Three supervisors were recruited and facilitate the data collection procedures. A two-day training was given for data collectors and supervisors on objective of the study, interview techniques and informed consent. Internal consistency was checked using Cronbach's alpha giving the value of 0.73 for items used to assess perception toward quarantine.

\section{Operational Definitions and}

\section{Measurements}

\section{Knowledge of COVID-19}

Knowledge of COVID-19 was measured by 26 yes or no items. Correct answers were coded as 1 and incorrect as 0 . The maximum score will be 26 while the minimum is 0 . Then those residents who answered more than half of the knowledge questions were considered as having good knowledge of COVID-19 otherwise it was poor. ${ }^{28,29}$

\section{Knowledge of Quarantine}

Knowledge of quarantine was measured by eight yes or no items. Correct answers were coded as 1 and incorrect as 0 . The maximum score will be eight while the minimum is 0 . Then those residents who answer more than half of the knowledge question were considered as having good knowledge of quarantine otherwise it was poor. ${ }^{28,29}$

\section{Perception Toward Quarantine}

Perception was measured by 15 Likert scale items: strongly disagree (1), disagree (2), neutral (3), agree (4) and strongly agree (5) and was adapted from related literatures. The reverse coding was done for negatively written questions. Sum score and mean score were computed. The sum score ranged between 15 and 75 . Then the higher the score indicates the more perception toward quarantine while the lower the score indicates negative perception toward quarantine. Based on mean score the respondents who scored above the mean score were considered as having positive perception otherwise negative perception toward quarantine. $^{28}$

\section{Data Processing and Analysis}

Data Processing and Analysis for Quantitative Study

The collected data were checked for completeness manually, and entered, cleaned and checked by EpiData manager version 4.0.2 and then exported to SPSS version 23 statistical packages for analysis. Descriptive analysis of different variables was presented in terms of frequencies, percentages and text. Simple (bivariate) linear regression was performed to select variables for multiple linear regression analysis. Then, variables with $p$-value $<0.25$ in the simple linear regression analysis were taken as candidates for multiple linear regression analysis.

At the end multiple linear regression analysis were performed to control for possible confounding effect of the selected variables and variables with $p$-value $<0.05$ will be taken as statistically significant association with community perception toward quarantine and OR with its $95 \% \mathrm{CI}$ was used to show the degree of association between the independent and outcome variables. Assumption of linear regression and multicollinearity were checked.

\section{Data Analysis for Qualitative Study}

The audiotape data recorded during interview was transcribed verbatim by the principal investigator. The transcribed data were then translated from local language to English language by an expert. Then, thematic analysis approaches were used and the principal investigator coded, categorized, and thematized the data by using Atlas.ti software version 7.0.71. The principal investigator started coding of the data after reading and rereading to become familiar with it.

\section{Data Quality Assurance}

A pretest was conducted on $5 \%$ of the sample size before the main study in Kite town. The data collected during the pretest was not included in final analysis part of the main study. A two-day training was given for data collectors and supervisors on how to collect data.

The data collection methods, tools and how to handle ethical issues was discussed with the data collectors. The questionnaire was translated into respondent's language during data collection. Regular supervision by the supervisor and the principal investigator was made to ensure that all necessary data was properly collected. Each day during data collection, filled questionnaires were checked for completeness and consistency. 


\section{Result}

\section{General Characteristics of the Study Participants}

The total of 816 study participants were interviewed making a response rate of $96.6 \%$. The median age of respondents were 30 years. From interviewed participants 450 (55.1\%) were male, 576 (70.6\%) were married, 269 (33\%) attended above secondary school, 447 (54.8\%) were orthodox Christian and $312(38.2 \%)$ of them were Kaffa in ethnicity. Table 1

\section{Sources of Information About COVID-19}

Six hundred and ninety-six $(85.3 \%)$ of the respondents heard about quarantine from TV while 354 (43.4\%) heard from the radio (Figure 1).

Table I Sociodemographic Characteristics of Adult Residents of Selected Towns of Southwest Ethiopia, June 2020

\begin{tabular}{|c|c|c|c|}
\hline Variables & Categories & Frequency & Percent \\
\hline \multirow[t]{2}{*}{ Sex } & Male & 450 & 55.1 \\
\hline & Female & 366 & 44.9 \\
\hline \multirow[t]{4}{*}{ Religion } & Orthodox & 447 & 54.8 \\
\hline & Protestant & 197 & 24.1 \\
\hline & Muslim & 168 & 20.6 \\
\hline & Catholic & 4 & 0.5 \\
\hline \multirow[t]{3}{*}{ Marital status } & Single & 189 & 23.2 \\
\hline & Married & 576 & 70.6 \\
\hline & Divorced and widowed & 51 & 6.3 \\
\hline \multirow{4}{*}{$\begin{array}{l}\text { Educational } \\
\text { status }\end{array}$} & No education & 88 & 10.8 \\
\hline & Primary education & 204 & 25.0 \\
\hline & Secondary education & 255 & 31.3 \\
\hline & Above secondary & 269 & 33.0 \\
\hline \multirow{5}{*}{$\begin{array}{l}\text { Ethnic } \\
\text { background }\end{array}$} & Bench & 129 & 15.8 \\
\hline & Amhara & 253 & 31.0 \\
\hline & Kaffa & 312 & 38.2 \\
\hline & Shekacho & 71 & 8.7 \\
\hline & Others $^{\mathrm{a}}$ & 51 & 6.3 \\
\hline \multirow[t]{6}{*}{ Occupation } & Housewife & 119 & 14.6 \\
\hline & Merchant & 219 & 26.8 \\
\hline & Government employee & 237 & 29.0 \\
\hline & Farmer & 51 & \\
\hline & Students & 106 & 13.0 \\
\hline & Daily Labor & 84 & 10.3 \\
\hline \multirow{2}{*}{$\begin{array}{l}\text { Living } \\
\text { arrangement }\end{array}$} & Live alone & 139 & 17.0 \\
\hline & $\begin{array}{l}\text { Live with one or more } \\
\text { person }\end{array}$ & 677 & 83.0 \\
\hline \multirow{2}{*}{$\begin{array}{l}\text { Presence radio/ } \\
\text { TV }\end{array}$} & Yes & 727 & 89.1 \\
\hline & No & 89 & 10.9 \\
\hline
\end{tabular}

Notes: ${ }^{a}$ Wolayita, Oromo, Silt'e, Sheko, Anuak.

\section{Knowledge of community about COVID-19}

The mean score of knowledge about COVID-19 was 13.41 (SD: 3.09). Four hundred and fifty-five (55.8\%) of the respondents have poor knowledge about COVID-19. Regarding the symptoms of the disease, $592(2.5 \%)$ of them mentioned dry cough followed by headache and sore throat, 428 (52.5) and 403 (49.4\%), respectively. Six hundred and eighty $(83.3 \%)$ of them mentioned direct contact with infected people as the main mode of transmission followed by droplet contacted from infected persons, 525 (64.3\%). Hand washing with soap and water was the main preventive mechanism mentioned by the majority of the respondents, $653(80 \%)$ (Table 2).

\section{Knowledge of Community About Quarantine}

The mean score of knowledge of quarantine was 5.98 (SD: 1.71). About two thirds, $522(64.0 \%)$ of the study participants have adequate knowledge about quarantine based on mean score (Table 3). The majority of in-depth interview participants also explained very well what quarantine is. For instance, a 44 years female participant explained quarantine as

Quarantine is the place where people suspected with COVID-19 stay for 2 weeks in order not to infect other community members. The person who is suspected for COVID-19 will be released from quarantine after 15 days when he/she is told by health professionals as he/ she is free of COVID-19.

The participants have also explained the use of quarantine correctly. A 39 years old male participants explained the importance of quarantine like this "Having quarantine is helpful because it reduces the chance of infection among the community members by putting the suspected people away from the community".

Mean scores difference for perception of quarantine was assessed by one-way ANOVA and independent sample $t$-test. A one-way ANOVA revealed that the mean quarantine perception score was significantly different by educational status $\left(\mathrm{F}_{3}, 812=17.31, p<0.001\right)$, occupational status $(\mathrm{F} 5,812=9.46, p<0.001)$. The post hoc test indicated that the mean perception score for educational status of secondary education was 56.72 (SD: 5.43) and above secondary education 54.18 (SD: 5.34) were significantly greater than the mean attitude score for educational status of no education and primary education. An independent 


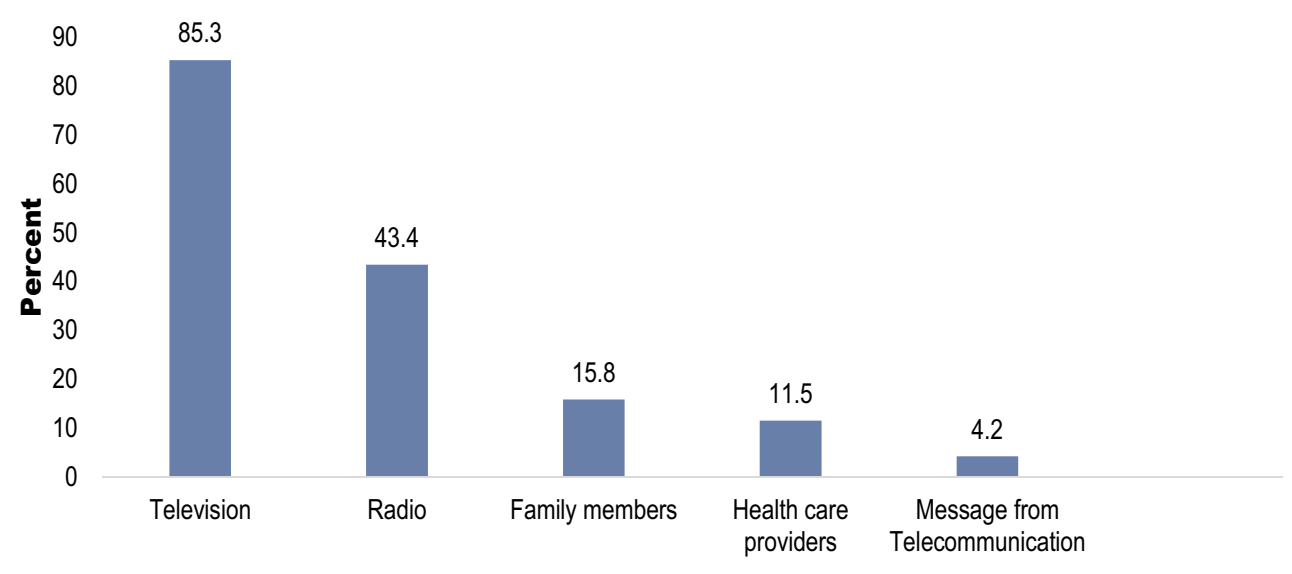

Sources of information

Figure I Sources of information about COVID-19 among adult residents of selected towns of Southwest Ethiopia, June 2020.

$t$-test indicated that the perception mean score of getting training and not trained were different $(t=-2.64, \mathrm{df}=814$, $p \leq 0.008$ ) Table 4 .

\section{Factors Associated with Perception of Quarantine}

In simple linear regression age of respondents, sex, presence of radio/TV, marital status, educational status, occupation, having training on COVID-19, knowledge of COVID-19 and quarantine were found to have a $p$-value of $<0.25$.

After controlling possible confounding variables in multiple linear regression, having training on COVID-19, educational status, occupation, knowledge of COVID-19, and knowledge of quarantine were significantly associated with perception toward quarantine. Having training on COVID-19 was among a factor positively associated with perception toward quarantine ie, when we change the status of training from nontrained to trained the perception toward quarantine score will be increased by 2.76 units keeping other variables constant $(\beta=2.76, p=0.005)$. When we change the educational status to secondary the perception score will be increased by 2.73 keeping other variables constant $(\beta=2.73, p=0.001)$. Similarly, when we change educational status to above secondary the perception mean score will be increased by 2.24 keeping other variables constant $(\beta=2.24, p=0.011)$. Being a merchant in occupational status was also associated with perception toward quarantine. As we change occupation to merchant the perception score will be increased by 1.73 keeping other variables constant $(\beta=1.73, p=0.020)$. Knowledge of
COVID-19 was also positively associated with perception score. When knowledge increase by one unit the perception score will increase by 0.23 keeping other variables constant ( $\beta=0.23, p=0.001$ ). Lastly, knowledge of quarantine positively affects the perception toward the quarantine. As knowledge of quarantine increase by one unit the perception of quarantine score increases by 0.59 keeping other variables unchanged $(\beta=0.59, p<0.001)$ Table 5 .

\section{Discussion}

The current study was aimed to assess community perception toward quarantine. Six hundred and ninety-six $(85.3 \%)$ of the respondents heard about quarantine from the TV while $354(43.4 \%)$ heard from the radio. In contrast to this, a study done in Turkey showed twothirds of the participants had never heard about COVID19 and more than half have not known what COVID-19 is. This discrepancy might be the result of an information gap related to time. In this study the main preventive mechanism mentioned by the majority of the respondents was hand washing with soap and water. Similarly, a study done on Turkish adults revealed that the mostly practiced preventive method were avoidance of public transportation and frequent handwashing with soap and water or alcohol-based hand rub. ${ }^{30}$ In addition, a study showed that the relationship between hope and resilience was mediated by preventive behaviors. ${ }^{31}$

The result of this study showed that only 427 (52.3\%) of the respondents have a positive perception toward quarantine. This indicates that efforts have to be made in increasing their perception through health information dissemination regarding the disease and quarantine. In this 
Table 2 Knowledge of COVID-19 Among Adult Residents of Selected Towns of Southwest Ethiopia, June 2020

\begin{tabular}{|c|c|c|c|}
\hline S.NO & Questions & $\begin{array}{l}\text { Correct } \\
\text { Answer } \\
\text { F (\%) }\end{array}$ & $\begin{array}{l}\text { Incorrect } \\
\text { Answer } \\
\text { F (\%) }\end{array}$ \\
\hline \multicolumn{4}{|c|}{$\begin{array}{l}\text { Can you tell me what you know about the symptoms of or how you } \\
\text { might know you have coronavirus? }\end{array}$} \\
\hline & $\begin{array}{l}\text { No known symptoms } \\
\text { Headache } \\
\text { Dry cough } \\
\text { Difficult of breathing } \\
\text { Sore throat }\end{array}$ & $\begin{array}{l}5(0.6) \\
428(52.5) \\
592(72.5) \\
307(37.6) \\
403(49.4)\end{array}$ & $\begin{array}{l}811(99.4) \\
388(47.5) \\
224(27.5) \\
509(62.4) \\
413(50.6)\end{array}$ \\
\hline \multicolumn{4}{|c|}{ How does the coronavirus spread/transmitted? } \\
\hline & $\begin{array}{l}\text { Through blood transfusion } \\
\text { Droplets from infected people } \\
\text { Direct contact with infected people } \\
\text { Touching contaminated objects/surfaces } \\
\text { Contact with contaminated animals } \\
\text { Mosquito bites } \\
\text { Eating contaminated food }\end{array}$ & $\begin{array}{l}806(98.8) \\
525(64.3) \\
680(83.3) \\
438(53.7) \\
192(23.5) \\
- \\
22(2.7)\end{array}$ & $\begin{array}{l}10(1.2) \\
291(35.7) \\
136(16.7) \\
378(46.3) \\
624(76.5) \\
816(100.0) \\
794(97.3)\end{array}$ \\
\hline \multicolumn{4}{|c|}{ How could coronavirus be prevented? } \\
\hline & $\begin{array}{l}\text { Has no known preventive method } \\
\text { Proper washing hand with soap and } \\
\text { water/sanitizer } \\
\text { Not touching the eye, nose by } \\
\text { unwashed hands } \\
\text { Avoid going to crowded places } \\
\text { Wearing masks } \\
\text { Do not shake hands } \\
\text { Stay home unless urgent } \\
\text { Quarantine, if contact with infected person } \\
\text { Isolation, if infected }\end{array}$ & $\begin{array}{l}765(93.8) \\
653(80.0) \\
284(34.8) \\
401(49.1) \\
528(64.7) \\
393(48.2) \\
227(27.8) \\
77(9.4) \\
36(4.4)\end{array}$ & $\begin{array}{l}51(6.3) \\
163(20.0) \\
532(65.2) \\
415(50.9) \\
288(35.3) \\
423(51.8) \\
589(72.2) \\
739(90.6) \\
780(95.6)\end{array}$ \\
\hline
\end{tabular}

study, $734(90 \%)$ of the respondents believed that quarantine is the best way to stop the spread of COVID-19. In contrast to this, a study conducted in South Korea revealed that most of the participants believed quarantine was ineffective to control Middle East respiratory syndrome
(MERS) or even increases risk of spreading MERS. ${ }^{32}$ This might be related to study time gap, as study conducted in South Korea was in 2015 so there is high information difference related to quarantine compared to the current study.

According to this study, having training on COVID-19 was positively associated with perception toward quarantine. This shows creating awareness through training has an effect on the perception of quarantine and the disease. This might be when confronting new and frightening diseases like COVID-19, training people to understand the reason for quarantine might increase belief in its effectiveness and thus, their compliance with quarantine. A qualitative study conducted on risk perception and compliance with quarantine during the SARS outbreak showed that all participants reportedly agreed with the need for quarantine and people adhered to the quarantine protocols with differing levels of awareness. ${ }^{33}$ Moreover, an untrained person may lack of clear information about the different levels of risk which might led to fearing the worst.

Participants who attended secondary education and above have more positive perception of quarantine. This shows attention has to give to those participants with a low level of educational status. Similarly, a study done in Toronto showed that education is needed about the meaning of quarantine, who needs to be quarantined and why, how diseases spread, and whose health is being protected by quarantine. ${ }^{22}$ In contrast to this, a study conducted in South Korea on Middle East respiratory syndrome risk perception among students at a university demonstrated that respondents with higher educational attainment held negative perception toward quarantine. ${ }^{32}$ This might be due to access to different written information related

Table 3 Knowledge of Quarantine and Perception of Quarantine Among Adult Residents of Selected Towns of Southwest Ethiopia, June 2020

\begin{tabular}{|l|l|l|}
\hline Statements & Correct Answers F (\%) & In Correct Answers F (\%) \\
\hline Quarantine is where COVID-19 infected people live & $37 I(45.5)$ & $445(54.5)$ \\
Quarantine is where people with contact history live & $474(58.1)$ & $342(41.9)$ \\
Quarantine is where COVID-19 infected patients treated & $742(90.9)$ & $74(9.1)$ \\
Quarantine is for those from countries of coronavirus case & $422(51.7)$ & $394(48.3)$ \\
Quarantine is important to protect oneself from coronavirus & $208(25.5)$ & $608(74.5)$ \\
Quarantine is important to protect households from coronavirus & $513(62.9)$ & $303(37.1)$ \\
Quarantine is important to protect communityfrom coronavirus & $429(52.6)$ & $387(47.4)$ \\
How long people stay in quarantine & $626(76.7)$ & $190(23.3)$ \\
\hline
\end{tabular}


Table 4 Comparison of Mean Score of Perception of Quarantine Among Different Explanatory Variables Among Adult Residents of Selected Towns of South West Ethiopia, June 2020

\begin{tabular}{|c|c|c|c|c|}
\hline Variable & Category & Mean (SD) & $\begin{array}{l}F \text { test/ } \\
t \text {-test }\end{array}$ & $p$-value \\
\hline Sex & $\begin{array}{l}\text { Male } \\
\text { Female }\end{array}$ & $\begin{array}{l}55.69(5.54) \\
55.62(6.17)\end{array}$ & $\begin{array}{l}t=0.18, \\
d f=741.5\end{array}$ & 0.073 \\
\hline $\begin{array}{l}\text { Training of } \\
\text { COVID-19 }\end{array}$ & $\begin{array}{l}\text { No } \\
\text { Yes }\end{array}$ & $\begin{array}{l}55.54(5.80) \\
58.03(6.10)\end{array}$ & $\begin{array}{l}t=-2.64, \\
d f=814\end{array}$ & 0.008 \\
\hline Marital status & $\begin{array}{l}\text { Single } \\
\text { Married } \\
\text { Divorced } \\
\text { Widowed }\end{array}$ & $\begin{array}{l}55.99(6.81) \\
55.66(5.48) \\
56.32(4.54) \\
48.85(5.06)\end{array}$ & $F_{3}, 812=6.41$ & $<0.001$ \\
\hline Age group & $\begin{array}{l}<20 \\
20-29 \\
30-39 \\
40-49 \\
\geq 50\end{array}$ & $\begin{array}{l}54.70(6.85) \\
55.75(6.14) \\
56.11(5.4 I) \\
54.98(5.68) \\
55.76(5.25)\end{array}$ & $F 4,81 I=1.17$ & 0.33 \\
\hline Religion & $\begin{array}{l}\text { Orthodox } \\
\text { Protestant } \\
\text { Muslim } \\
\text { Catholic }\end{array}$ & $\begin{array}{l}55.82(5.75) \\
55.08(6.03) \\
56.17(5.65) \\
45.50(0.58)\end{array}$ & $F 3,812=5.31$ & 0.001 \\
\hline $\begin{array}{l}\text { Educational } \\
\text { status }\end{array}$ & $\begin{array}{l}\text { No education } \\
\text { Primary } \\
\text { Secondary } \\
\text { Above } \\
\text { secondary }\end{array}$ & $\begin{array}{l}52.82(4.86) \\
54.25(6.28) \\
56.64(5.64) \\
56.72(5.43)\end{array}$ & $F_{3}, 812=\mid 7.31$ & $<0.001$ \\
\hline $\begin{array}{l}\text { Occupational } \\
\text { status }\end{array}$ & $\begin{array}{l}\text { Housewife } \\
\text { Merchant } \\
\text { Government } \\
\text { employee } \\
\text { Farmer } \\
\text { Students } \\
\text { Daily labor }\end{array}$ & $\begin{array}{l}54.18(5.34) \\
56.52(5.63) \\
56.96(5.28) \\
52.98(6.99) \\
55.51(6.49) \\
53.67(5.44)\end{array}$ & $F_{5}, 8 \mid 2=9.46$ & $<0.001$ \\
\hline
\end{tabular}

to COVID-19 by educated persons. From the occupation of the respondent's, merchants have a more positive perception of quarantine. This might be related to a merchant's contacts with different individuals that helps to get information from different people.

The finding from this study also revealed that knowledge of COVID-19 was associated with more positive perception of quarantine. This might be respondents who have knowledge of COVID-19 may have information regarding the prevention of the disease since quarantine is also one option of COVID-19 control. Finally, the knowledge of quarantine was associated with perception of quarantine. Respondents who have knowledge of quarantine have a more positive perception of
Table 5 Factors Associated with Perception of Quarantine Among Adult Residents of Selected Towns in Southwest Ethiopia, June, 2020

\begin{tabular}{|c|c|c|c|c|}
\hline \multirow[t]{2}{*}{ Variables } & \multirow{2}{*}{$\begin{array}{l}\beta \\
\text { Coefficients }\end{array}$} & \multirow[t]{2}{*}{$p$-value } & \multicolumn{2}{|c|}{$95 \% \mathrm{Cl}$ for $\beta$} \\
\hline & & & $\begin{array}{l}\text { Lower } \\
\text { Bound }\end{array}$ & $\begin{array}{l}\text { Upper } \\
\text { Bound }\end{array}$ \\
\hline Constant & 45.72 & $<0.001$ & 42.48 & 48.96 \\
\hline Age & 0.02 & 0.49 & -0.03 & 0.06 \\
\hline Sex & 0.11 & 0.82 & -0.83 & 1.04 \\
\hline Presence of radio/TV & 0.13 & 0.85 & -1.22 & 1.48 \\
\hline $\begin{array}{l}\text { Having training on } \\
\text { COVID-19 }\end{array}$ & 2.76 & 0.005 & 0.84 & 4.69 \\
\hline No education & RG & & & \\
\hline Primary education & 0.97 & 0.220 & -0.58 & 2.52 \\
\hline Secondary education & 2.73 & 0.001 & 1.17 & 4.29 \\
\hline $\begin{array}{l}\text { Above secondary } \\
\text { education }\end{array}$ & 2.24 & 0.011 & 0.51 & 3.98 \\
\hline Single & RG & & & \\
\hline Married & -0.05 & 0.936 & -1.28 & 1.18 \\
\hline Divorced & -1.36 & 0.185 & -3.38 & 0.65 \\
\hline Housewife & RG & & & \\
\hline Merchant & 1.73 & 0.020 & 0.27 & 3.20 \\
\hline Government employee & 1.43 & 0.097 & -0.26 & 3.11 \\
\hline Farmer & -0.67 & 0.516 & -2.69 & 1.36 \\
\hline Students & 0.74 & 0.453 & -1.19 & 2.68 \\
\hline Daily labor & -0.59 & 0.517 & -2.36 & 1.19 \\
\hline Knowledge of COVID-19 & 0.23 & 0.001 & 0.09 & 0.36 \\
\hline Knowledge of quarantine & 0.59 & $<0.001$ & 0.35 & 0.83 \\
\hline
\end{tabular}

quarantine. The systematic review conducted on how to improve adherence with quarantine also showed that the knowledge people had about the disease and quarantine procedures were the main factors that affect adherence to quarantine. ${ }^{34}$

\section{Limitation of the Study}

- On some questions, community may hide the actual response ie, social desirability bias may affect the study. In addition to this it may susceptible to interviewer bias.

- Reverse causality: it is difficult to determine whether the exposure (factors associated) or outcome (perception toward quarantine) came first.

\section{Conclusion}

Only $52.3 \%$ of the respondents have positive perception toward quarantine. Factors associated with perception toward quarantine were having training on COVID-19, 
Table 6 A Frequency Table Showing Perception Toward Quarantine Among Adult Residents of Selected Towns of Southwest Ethiopia, June 2020

\begin{tabular}{|c|c|c|c|}
\hline Statements & $\begin{array}{l}\text { Disagree and } \\
\text { Strongly Disagree } \\
\text { F (\%) }\end{array}$ & $\begin{array}{l}\text { Neutral } \\
\text { F (\%) }\end{array}$ & $\begin{array}{l}\text { Agree and } \\
\text { Strongly Agree } \\
\text { F (\%) }\end{array}$ \\
\hline Quarantines is the best way to stop spread of coronavirus COVID-19 & $55(6.7)$ & $27(3.3)$ & $734(90.0)$ \\
\hline $\begin{array}{l}\text { If I go into quarantine, my family/friends/community will be protected from } \\
\text { becoming sick }\end{array}$ & $49(6.0)$ & $40(4.9)$ & $727(89.1)$ \\
\hline Staying in quarantine makes me afraid/panic & $626(76.7)$ & $49(6.0)$ & $14 \mid(17.3)$ \\
\hline People may stigmatize quarantined individual upon discharge from quarantine & $155(19.0)$ & $65(8.0)$ & $596(73.0)$ \\
\hline I think there is not enough food and water in quarantine & $544(66.7)$ & $87(10.7)$ & $185(22.7)$ \\
\hline Quarantine place in not convenient for living & $592(72.5)$ & $77(9.4)$ & $147(18.0)$ \\
\hline Quarantines expose individuals to infection & $557(68.3)$ & $87(10.7)$ & $172(2||)$. \\
\hline $\begin{array}{l}\text { Government should have the power to order people into quarantine during } \\
\text { outbreaks }\end{array}$ & $66(8.1)$ & $56(6.9)$ & $694(85.0)$ \\
\hline $\begin{array}{l}\text { If someone is given a quarantine order by Public Health, they should follow it no } \\
\text { matter what else is going on in their life at work or home }\end{array}$ & $58(7.1)$ & $56(6.9)$ & $702(86.0)$ \\
\hline $\begin{array}{l}\text { People who break quarantine orders on purpose should face legal penalties like } \\
\text { a fine or jail }\end{array}$ & $50(6.1)$ & $\begin{array}{l}195 \\
(23.9)\end{array}$ & $571(70.0)$ \\
\hline Public Health should ensure that there is no discrimination in the use of quarantine & $77(9.4)$ & $\begin{array}{l}165 \\
(20.2)\end{array}$ & $574(70.3)$ \\
\hline $\begin{array}{l}\text { It is reasonable for some rights to be taken away during an infectious disease } \\
\text { outbreak }\end{array}$ & $46(5.6)$ & $\begin{array}{l}173 \\
(21.2)\end{array}$ & $597(73.2)$ \\
\hline For me staying quarantine for 15 days is useful & $69(8.5)$ & $62(7.6)$ & $685(83.9)$ \\
\hline For me staying quarantine for 15 days is difficult & $46 \mid(56.5)$ & $74(9.1)$ & $281(34.4)$ \\
\hline I will stay in quarantine if I am advised to do so & $122(15.0)$ & $55(6.7)$ & $639(78.3)$ \\
\hline Overall mean score & 3.48 (SD: 0.36) & & \\
\hline
\end{tabular}

Abbreviation: $F(\%)$, frequency (percent).

educational status of secondary, educational status of above secondary, being a merchant, knowledge of COVID-19 and knowledge of quarantine. Concerned bodies should work on enhancing the awareness of community and communication campaigns by producing different information education and communication/behavior changing communication materials needed on issues related to quarantine and COVID-19 prevention.

\section{Data Sharing Statement}

The data set is available with authors and can be obtained from the corresponding author upon reasonable request.

\section{Ethics Approval and Consent to Participate}

This study was conducted in accordance with the Declaration of Helsinki. Ethical clearance was obtained from the Institutional Review Board of Mizan-Tepi University. Permission was obtained from each selected town health office to collect data from the community. Written consent was obtained from all study participants before interview. Participation in the study was completely voluntary, and the right to withdraw from the interview also secured. The participant was also informed that anonymized responses would be published.. Confidentiality of the information was ensured throughout the study.

\section{Acknowledgments}

The authors are very grateful for Mizan-Tepi University, the study participants, data collectors and supervisors.

\section{Author Contributions}

All authors contributed to data analysis, drafting or revising the article, have agreed on the journal to which the article will be submitted, gave final approval of the version to be published, and agree to be accountable for all aspects of the work.

\section{Funding}

This study was funded by Mizan-Tepi University. 


\section{Disclosure}

The authors report no conflicts of interest in this work.

\section{References}

1. COVID-19 infection risk in pakistani health-care workers: The costeffective safety measures for developing countries.

2. Song F, Shi N, Shan F. Emerging 2019 Novel Coronavirus (2019-nCoV) Pneumonia. Radiology. 2020;295(1):210-217. doi:10.1148/radiol.2020200274

3. WHO. Coronavirus disease (COVID-19) pandemic. Available from: https://www.who.int/emergencies/diseases/novel-coronavirus-2019? gclid.Accessed September 18, 2020.

4. Capuzzi D, Gross DR. Introduction to the Counseling Profession: Seventh Edition; 2017. New York: Routledge. doi:10.4324/9781315537061

5. CDC. Issues to Consider Isolation Quarantine; 2006.

6. Michigan Department of community Health. Isolation \& Quarantine Information for the Public; 2013.

7. European Center for Disease Prevention and Control. Guidelines for the use of non-pharmaceutical measures to delay and mitigate the impact of. 2019-nCoV. Tech Rep. 2020:10.

8. ICMHD. Notes on Community Quarantine; 2020.

9. European Centre for Disease Prevention and Control. Resource estimation for contact tracing, quarantine and monitoring activities for COVID-19 cases in the EU/EEA (ECDC Technical Report). 2020. 1-9.

10. Center of the Disease Control. Understand Quarantine and Isolation.

11. Bondy SJ, Russell ML, Laflèche JM, Rea E. Quantifying the impact of community quarantine on SARS transmission in Ontario: estimation of secondary case count difference and number needed to quarantine. BMC Public Health. 2009;9(1):1-10. doi:10.1186/14712458-9-488

12. Tang B, Wang X, Li Q, et al. Estimation of the Transmission Risk of the 2019-nCoV and Its Implication for Public Health Interventions. J Clin Med. 2020;9(2):462. doi:10.3390/jcm9020462

13. UNCTAD. The Covid-19 Shock to Developing Countries: Towards a Whatever It Takes Programme for the Two-Thirds of the World's Population Being Left Behind; 2020.

14. FAO. Addressing the Impacts of COVID-19 in Food Crises. Vol. 2020. 2019. doi: $10.4060 / \mathrm{ca} 8497 \mathrm{en}$

15. WHO | Regional Office for Africa; Scaling up coronavirus outbreak readiness in Ethiopia. Available from: https://www.afro.who.int/ photo-story/scaling-coronavirus-outbreak-readiness-ethiopia. Accessed September 20,2020.

16. AfricaNews, Coronavirus - Ethiopia: notification on Situational COVID 19 Update. Available from: https://www.africanews.com/ 2020/04/04/coronavirus-ethiopia-notification-on-situational-covid -19-update.Africanews2020. Accessed September 20, 2020.

17. Wendy E, Armet JD, Sinha MS. Covid-19 - the Law and Limits of Quarantine. N Engl J Med. 2020;28(1):1-3.

18. Yıldırım M, Güler A. Preventive behaviors, and mental health in Turkey. Death Stud. 2020;1-8. doi:10.1080/07481187.2020.1793434

19. Dryhurst S, Schneider CR, Kerr J, et al. Risk perceptions of COVID-19 around the world. J Risk Res. 2020:1-13. doi:10.1080/ 13669877.2020 .1758193

20. World Health Organization (WHO). Novel Coronavirus (2019-nCoV); 2020.
21. Mcguire T, Rowe J, Cole K, Herr C, Hs T. Psychosocial Correlates of Outbreak Response Activities: A Supplemental Literature Report. 2020;1-10.

22. DiGiovanni C, Conley J, Chiu D, Zaborski D. Factors influencing compliance with quarantine in Toronto during the 2003 SARS outbreak. Biosecurity Bioterrorism Biodefense Strateg Pract Sci. 2003;2(4):265-272. doi:10.1089/bsp.2004.2.265

23. Info A. Letter to the Editor Aggregated COVID-19 suicide incidences in India: fear of COVID-19 infection is the prominent. Emerg Infect Dis. 2020;290:17-20. doi:10.1016/j.psychres.2020.113145

24. Bhuiyan AKMI, Sakib N, Pakpour AH, Griffiths MD, Mamun MA. COVID-19-Related Suicides in Bangladesh Due to Lockdown and Economic Factors: case Study Evidence from Media Reports. International Journal of Mental Health and Addiction. 2020. doi:10.1007/s11469-020-00307-y

25. Tognotti E. Lessons from the history of quarantine, from plague to influenza A. Emerg Infect Dis. 2013;19(2):254-259. doi:10.3201/ eid1902.120312

26. Chinn S. Review Author (s): susan Chinn Review by: susan Chinn Source: journal of the Royal Statistical Society. Series C (Applied Statistics), Vol. 28, No. 3 Published by: wiley for the Royal Statistical Society Stable. J infect dis. 2016;28(3):307-308. http://www.jstor. org/stable.

27. Tracy CS, Rea E, Upshur RE. Public perceptions of quarantine: community-based telephone survey following an infectious disease outbreak. BMC Public Health. 2009;9(1):1-8. doi:10.1186/14712458-9-470

28. Zeleke H, Gualu T, Sharew Y, Knowledge AG. Practice and Attitude towards Epilepsy and Associated Factors among Adults in Goncha Siso Enesie Woreda Rural Kebeles, East Gojjam, Ethiopia 2016. Epilepsy J. 2018;04(02):02. doi:10.4172/2472-0895.1000126

29. Kaddumukasa M, Kakooza A, Kayima J, et al. Community knowledge and attitudes of epilepsy in rural and urban Mukono district, Uganda; a cross sectional study. Epilepsy Behav. 2017:7-11. doi:10.1016/j.yebeh.2015.10.023.Community

30. Yıldırım M, Geçer E, Akgül Ö. The impacts of vulnerability, perceived risk, and fear on preventive behaviours against COVID-19. Psychol Health Med. 2020;1-9. doi:10.1080/13548506.2020.1776891

31. Yildırım M, Arslan G. Exploring the Associations Between Resilience, Dispositional Hope, Preventive Behaviours, Subjective Well-Being, and Psychological Health Among Adults During Early Stage of COVID-19. 2020.

32. Kim EY, Liao Q, Yu ES, et al. American Journal of Infection Control Middle East respiratory syndrome in South Korea during 2015: risk-related perceptions and quarantine attitudes. AJIC Am J Infect Control. 2016;44(11):1414-1416. doi:10.1016/j.ajic.2016.03.014

33. Cava MA, Fay KE, Beanlands HJ, McCay EA, Wignall R. Risk perception and compliance with quarantine during the SARS outbreak. J Nurs Scholarsh. 2005;37(4):343-347. doi:10.1111/ j.1547-5069.2005.00059.x

34. Webster RK, Brooks SK, Smith LE, Woodland L, Wessely S, Rubin GJ. How to improve adherence with quarantine: rapid review of the evidence. Public Health. 2020;182:163-169. doi:10.1016/j. puhe.2020.03.007 


\section{Publish your work in this journal}

The International Journal of General Medicine is an international, peer-reviewed open-access journal that focuses on general and internal medicine, pathogenesis, epidemiology, diagnosis, monitoring and treatment protocols. The journal is characterized by the rapid reporting of reviews, original research and clinical studies across all disease areas. The manuscript management system is completely online and includes a very quick and fair peer-review system, which is all easy to use. Visit http://www.dovepress.com/ testimonials.php to read real quotes from published authors.

Submit your manuscript here: https://www.dovepress.com/international-journal-of-general-medicine-journal 